\title{
Formation and function of GnRH-induced subnormal corpora lutea in cyclic ewes
}

\author{
D. H. Keisler and L. W. Keisler \\ Animal Sciences Department, University of Missouri, Columbia, Missouri 65211, USA
}

\begin{abstract}
Summary. Of 19 dioestrous ewes given $50 \mu \mathrm{g} \mathrm{GnRH}$ on Day 10 of the oestrous cycle, 15 $(79 \%)$ formed corpora haemorrhagica within 2 days after injection of GnRH. After excision of the Day 10 spontaneous $\mathrm{CL}$, the GnRH-induced CL were short lived when compared to spontaneous $C L$ in saline-treated ewes $(3.1 \pm 0.4$ vs $17.3 \pm 0.3$ days, respectively). Hysterectomy of ewes bearing the $\mathrm{GnRH}$-induced $\mathrm{CL}$ prevented regression of the short-lived CL, thus extending functional lifespan $\geq 38$ days. Serum concentrations of progesterone produced by the GnRH-induced CL in hysterectomized ewes were less than those observed during a comparable interval (Days 7-14) in salinetreated, non-hysterectomized ewes $(2.24 \pm 0.1$ vs $3.67 \pm 0.15 \mathrm{ng} / \mathrm{ml}$, respectively; $P \leqslant 0.001)$.

When GnRH was given before ( $5 \mathrm{~h}$ before) or during ( $5 \mathrm{~h}$ after) PGF-2 $\alpha$-induced regression of the Day 10 spontaneous $\mathrm{CL}$, the $\mathrm{GnRH}$-induced CL which formed were also short-lived. In contrast, when GnRH was given following ( $36 \mathrm{~h}$ after) PGF-2 $\alpha$ induced regression of the Day 10 spontaneous $\mathrm{CL}$, the $\mathrm{CL}$ which formed were not different in lifespan or production of progesterone from spontaneous CL. Efforts to enhance function of the GnRH-induced subnormal CL by treating ewes with the synthetic progestagen, norgestomet, to suppress follicular development after CL formation, were unsuccessful.

We suggest that these results provide new evidence to support the hypothesis that subnormal luteal function may be the result of inadequate follicle development (i.e. the follicle needs exposure to some sequence of events characteristic of luteal regression and/or a normal follicular phase) which impairs uterine luteolytic mechanisms. These results also support the hypothesis that periovulatory determinants of normal luteal function are established between 5 and $36 \mathrm{~h}$ after PGF- $2 \alpha$-induced luteal regression.
\end{abstract}

Keywords: corpus luteum; ewes; hysterectomy; GnRH

\section{Introduction}

Subnormal luteal function has been considered to be an important cause of infertility and is known to occur in women (Strott et al., 1970), monkeys (Wilks et al., 1976), cows (Pratt et al., 1982), and ewes (Coleman \& Dailey, 1983; McLeod \& Haresign, 1984). Characteristically, subnormal corpora lutea (CL) will function for an abbreviated period of time, producing normal or subnormal serum concentrations of progesterone, or will function for a normal period of time, producing subnormal concentrations of progesterone (see review by Garverick \& Smith, 1986). Deficiencies in either the duration of progesterone secretion or amount secreted have been associated with failure to maintain pregnancy in women (Jones, 1976; Soules et al., 1977). Factors responsible for the formation and function of spontaneously formed subnormal CL have not been elucidated due in part to the difficulty in predicting their occurrence. In cattle and sheep, subnormal CL often form at the onset of puberty and at the initiation of cyclic activity following seasonal or post-partum anoestrus; both 
relatively unpredictable events (Corah et al., 1974; Walton et al., 1977; Berardinelli et al., 1979, 1980; Lamming et al., 1981; LaVoie et al., 1981; Keisler et al., 1983; Sharpe et al., 1986). Several experimental approaches have been used to enhance the predictability of the occurrence of subnormal CL (Lishman et al., 1979; Odde et al., 1980; Pratt et al., 1982; Garcia-Winder et al., 1986; Copelin et al., 1987; Southee et al., 1988a). These approaches, however, either lack desired precision or are dependent on the induction of both normal and subnormal $\mathrm{CL}$ in anoestrous animals. Rahmanian \& Murdoch (1987) described a system for GnRH induction of subnormal CL in cyclic ewes which would facilitate the study of periovulatory events. They reported, however, that the subnormal $\mathrm{CL}$ which were induced were not dependent on the uterus for their demise. We have re-examined the role of the uterus in the demise of the subnormal CL induced as described by Rahmanian \& Murdoch (1987), and further investigated follicular determinants of CL formation and function.

\section{Materials and Methods}

Ninety-two mature, regularly cycling, 1/4 Finn $\times 1 / 4$ Dorset $\times 1 / 2$ Rambouillet crossbred ewes were used. Ewes were maintained on pasture with brisket-painted vasectomized rams to facilitate detection of oestrus. Ewes were checked for oestrus each morning and evening using fresh vasectomized rams. The day of oestrus was equated to Day 0 . All studies were conducted well within the normal breeding season of the flock, between the months of October and December.

Experiment 1. The objective of Exp. 1 was to determine the lifespan of CL induced during the luteal phase and the role of the uterus in their demise. Ewes were randomly assigned to receive an i.m. injection of either $50 \mu \mathrm{g} \mathrm{GnRH}$ suspended in $1 \mathrm{ml} \mathrm{0.9 \% (w/v)} \mathrm{NaCl}$ (Cystorelin: Ceva Laboratories, Overland Park, Kansas 66212, USA; $\mathrm{N}=19$ ) or $1 \mathrm{ml} 0.9 \%(w / v) \mathrm{NaCl}(\mathrm{N}=8)$ on Day 10 of the oestrous cycle. All ewes were laparotomized $36 \mathrm{~h}$ later via a midventral incision and the ovaries examined to determine whether treatment had induced new CL to form in the presence of spontaneous (Day 11) CL. Spontaneous CL were surgically removed from the ovaries of ewes which formed induced $C L(N=15)$, thus permitting a study of the functional capacity of the induced $C L$. Seven of these 15 ewes were then hysterectomized to study the role of the uterus in the demise of the induced CL. Serum concentrations of progesterone were determined in jugular blood samples collected each day after injection of GnRH until ewes were either observed in oestrus or were 38 days after surgery.

Experiment 2. In Exp. 2, the objective was to determine the relationship between function of GnRH-induced CL and time at which they were induced to form relative to PGF-2 $\alpha$-initiated regression of spontaneous CL. The 29 ewes were randomly assigned to receive one of four treatments. On Day 10 of the oestrous cycle all ewes were treated with two 1-ml injections of 5 mg PGF-2 $\alpha$ (Lutalyse: The UpJohn Co., Kalamazoo, Michigan 49001, USA) given i.m. $3 \mathrm{~h}$ apart. Eight ewes were assigned to the treatment group designated PG and received no further injections. The remaining 21 ewes received an i.m. injection of $50 \mu \mathrm{g} \mathrm{GnRH} 5 \mathrm{~h}$ before, $5 \mathrm{~h}$ after or $36 \mathrm{~h}$ after the first injection of PGF-2 $\alpha$ (treatment groups $=\mathrm{GnRH}-5 \mathrm{~h}-\mathrm{PG}, \mathrm{PG}-5 \mathrm{~h}-\mathrm{GnRH}$ and $\mathrm{PG}-36 \mathrm{~h}-\mathrm{GnRH}$, respectively; $\mathrm{N}=7 /$ group) to initiate GnRH-induced CL formation before, during or after luteal regression. Jugular blood samples were collected from ewes in the $3 \mathrm{GnRH}$ treatment groups at 30 -min intervals for $5 \mathrm{~h}$ beginning immediately after the injection of $\mathrm{GnRH}$ and from the PG-treated ewes at $2-\mathrm{h}$ intervals for $24 \mathrm{~h}$ beginning $36 \mathrm{~h}$ after the initial injection of PGF-2 $\alpha$. These samples were assayed for serum LH to determine the GnRH-induced LH response in the GnRH-treated ewes and the onset of the preovulatory surge of LH in the PG-treated ewes. A second set of jugular blood samples was collected from ewes in each of the 4 treatment groups every $3 \mathrm{~h}$ for $15 \mathrm{~h}$ after the initial injection of PGF-2 $\alpha$ and subsequently each day for 22 days. These samples were assayed for progesterone to characterize the PGF-2 $\alpha$-induced decline in progesterone secretions by the spontaneous $\mathrm{CL}$ and functional aspects of $\mathrm{CL}$ which formed after treatments. Corpora lutea which formed following treatments were visualized via ventral laparoscopy performed under local anaesthesia. Multiple laparoscopies were performed to establish an association between luteal structures and progesterone profiles.

Experiment 3. The objective of Exp. 3 was to determine whether GnRH-induced subnormal luteal function could be enhanced by treating ewes with a synthetic progestagen (norgestomet) to suppress subsequent follicular development after CL formation. Ewes were randomly assigned to receive the $\mathrm{GnRH}-5 \mathrm{~h}-\mathrm{PG}(\mathrm{N}=20)$ or $\mathrm{PG}-36 \mathrm{~h}-\mathrm{GnRH}$ $(N=16)$ treatment described in Exp. 2. Ovarian responses of ewes to treatments were determined via laparoscopy 2 days after injection of GnRH. Ewes without corpora haemorrhagica were not studied further. Ewes with corpora haemorrhagica were implanted subcutaneously at the time of laparoscopy with either a hydron polymer ear implant containing $3 \mathrm{mg}$ norgestomet or a control ear implant for 8 days. Norgestomet was used because it did not cross-react with progesterone in our progesterone assay. Following implant placement, ewes were checked for oestrus and blood was collected for determination of serum progesterone twice daily until ewes were detected in oestrus. Ewes detected in oestrus before implant removal were assessed at oestrus, via laparoscopy, for gross ovarian structural changes 
occurring subsequent to the initial laparoscopy. Ewes not in oestrus before implant removal were similarly assessed via laparoscopy at implant removal. Norgestomet was from Ceva Laboratories Inc. (Overland Park, KS, USA).

Assay procedures. Concentrations of progesterone were determined in duplicate samples of 50 or $200 \mu$ serum per tube by radioimmunoassay procedures described by Sheffel et al. (1982) and established in our laboratory. Minimum detectable concentrations were $5 \mathrm{pg} /$ tube; recovery averaged $89 \%$ and inter- and intra-assay coefficients of variation were $6 \%(n=12)$ and $11 \%(n=5)$, respectively. Assay blanks were $<1 \mathrm{pg} /$ tube. Concentrations of LH were determined in duplicate in 20 or $200 \mu \mathrm{l}$ serum per tube by the radioimmunoassay procedures described by Zaied $e t$ al. (1980). Minimum detectable concentration of $\mathrm{LH}$ was $25 \mathrm{pg} /$ tube with inter- and intra-assay coefficients of variation of $9 \%(n=3)$ and $12 \%(n=7)$, respectively.

Statistical methods. Comparisons among treatments were made using analysis of variance procedures and, when appropriate, Duncan's new multiple range test (Steel \& Torrie, 1980). Effects of treatment on serum concentrations of LH and progesterone were determined using the general linear models procedure of the Statistical Analysis System (SAS Institute Inc., 1985) for a split-plot design with repeated measures in time. Treatment was a main plot variable with time, and time by treatment interactions were subplot variables. Differences with a probability of $5 \%$ or less were considered significant. Estimates of repeatability were calculated in Exp. 1 using a nested analysis of variance procedure described by Becker (1984).

\section{Results}

\section{Experiment 1}

Of the 19 ewes injected with GnRH on Day 10 of the oestrous cycle, 15 formed induced CL in the presence of spontaneous $\mathrm{CL}$ as determined by laparotomy performed $36 \mathrm{~h}$ after the injection of GnRH (Table 1). Induced CL appeared upon gross observation as new ovulation sites. Greater numbers of spontaneous $\mathrm{CL}$ were present in the ovaries of ewes at laparotomy than were induced to form in response to $\mathrm{GnRH}(2 \pm 0$ vs $1.6 \pm 0.2 \mathrm{CL}$, respectively; $P \leqslant 0.05)$. Formation of induced CL occurred with little preference for the ovary bearing spontaneous CL (repeatability $=$ $0.33 ; P \leqslant 0.05$ ). Oestrus did not precede the formation of induced CL. Lifespan of induced CL in GnRH-treated non-hysterectomized ewes was shorter than that of spontaneous CL in salinetreated ewes (Table 1). However, lifespan of spontaneous CL did not differ $(P \geq 0 \cdot 10)$ in saline- or GnRH-treated ewes which failed to form induced CL. Serum concentrations of progesterone in non-hysterectomized ewes which formed induced CL never exceeded $0.5 \mathrm{ng} / \mathrm{ml}$ for more than 1 day before returning to oestrus. Removal of the uterus from ewes which formed induced CL prevented regression of the induced CL and return to oestrus during the 38-day period of study following hysterectomy. Serum concentrations of progesterone in hysterectomized ewes with induced CL increased after hysterectomy and remained plateaued for the duration of study at a concentration less than that observed during a comparable interval (Days 7-14) in saline-treated ewes $(2 \cdot 24 \pm 0 \cdot 1$ vs $3.67 \pm 0.15 \mathrm{ng} / \mathrm{ml}$, respectively; $P \leqslant 0.001)$.

\section{Experiment 2}

Two injections of $5 \mathrm{mg}$ PGF-2 $\alpha$, given $3 \mathrm{~h}$ apart, initiated a decline in serum concentrations of progesterone in each of the 29 ewes. Mean concentrations of progesterone determined during the interval encompassing luteal regression did not differ $(P \geq 0 \cdot 10)$ with respect to treatment, time or the interaction of treatment and time.

Injection of $50 \mu \mathrm{g} \mathrm{GnRH}$ before (GnRH-5 h-PG), during (PG-5 h-GnRH) or after (PG-36 hGnRH) the PGF-2 $\alpha$-induced luteal regression prompted an immediate increase in serum concentrations of LH in GnRH-treated ewes. Maximum concentrations of $\mathrm{LH}$ were observed 1.5-2 h after injection of GnRH. Ewes which received the PG treatment spontaneously elicited a preovulatory surge of LH $53 \pm 6 \mathrm{~h}$ after the initial injection of PGF-2 $\alpha$. Magnitude of the surge of LH was greater $(P \leqslant 0.05)$ in PG-treated ewes $(94.3 \pm 21.3 \mathrm{ng} / \mathrm{ml})$ and ewes treated with GnRH after PGF-2 $\alpha$-induced luteal regression (PG-36 h-GnRH; $71 \cdot 2 \pm 17 \cdot 8 \mathrm{ng} / \mathrm{ml}$ ) than in ewes given $\mathrm{GnRH}$ before (GnRH-5h-PG) or during (PG-5h-GnRH) the PGF-2 $\alpha$-induced luteal regression $(20.2 \pm 1.7$ and $20.5 \pm 3.8 \mathrm{ng} / \mathrm{ml}$, respectively). Profiles of mean concentrations of LH determined 
Table 1. Number and type of CL present at surgery and their lifespan in ewes treated on Day 10 of the oestrous cycle with saline or $50 \mu \mathrm{g} \mathrm{GnRH}$ and treated surgically (laparotomy, CL excision, or CL excision + hysterectomy) $36 \mathrm{~h}$ later

\begin{tabular}{|c|c|c|c|c|}
\hline $\begin{array}{l}\text { Injection on } \\
\text { Day } 10\end{array}$ & $\begin{array}{c}\text { Surgical } \\
\text { procedure }\end{array}$ & $\begin{array}{l}\text { Proportion } \\
\text { of ewes with } \\
\text { induced CL }\end{array}$ & $\begin{array}{l}\text { Mean no. of } \\
\text { induced CL } \\
\text { per ewe }\end{array}$ & $\begin{array}{c}\text { Mean CL } \\
\text { lifespans } \\
\text { (days) }\end{array}$ \\
\hline \multirow{5}{*}{$\begin{array}{l}\text { Saline } \\
\text { GnRH } \\
\text { GnRH } \\
\text { GnRH }\end{array}$} & Laparotomy & $0 / 8$ & 0 & $17.3 \pm 0.3 \dagger$ \\
\hline & Laparotomy & $0 / 4$ & 0 & $17.5 \pm 0.3 \dagger$ \\
\hline & CL excision & $8 / 8$ & $1.8 \pm 0.3$ & $3.1 \pm 0.4^{*} \ddagger$ \\
\hline & CL excision + & & & \\
\hline & hysterectomy & $7 / 7$ & $1.5 \pm 0.2$ & $\geq 38^{*} \ddagger$ \\
\hline
\end{tabular}

†Spontaneous CL lifespans presented as mean inter-oestrus interval.

$\$$ Presented as mean number of days from surgical verification of the induced $C L$ (i.e. $36 \mathrm{~h}$ after an injection of $\mathrm{GnRH})$ to oestrus ( $\mathrm{GnRH}+\mathrm{CL}$ excision) or to the end of the study (GnRH + CL excision + hysterectomy).

${ }^{*} P \leq 0.001$ when compared to lifespans of spontaneous $\mathrm{CL}$ in saline- and GnRHtreated ewes in which no induced CL formed.

during the 5-h interval after injection of GnRH did not differ $(P \geq 0 \cdot 10)$ among PG- and PG-36 hGnRH-treated ewes or among ewes given GnRH before (GnRH-5 h-PG) or during (PG-5 hGnRH) luteal regression, but did differ $(P \leqslant 0.05)$ when comparisons were made between the two groupings.

Oestrus was observed in 8/8 PG-treated ewes beginning $2.2 \pm 0.5$ days after injection of PGF$2 \alpha$. Laparoscopies performed when ewes were first observed in oestrus following the PG treatment and again 2 days later, revealed that corpora haemorrhagica with visible papilli had formed in $8 / 8$ PG-treated ewes by the time of the 2nd laparoscopy. Subsequently, the PG-treated ewes returned to oestrus $19 \cdot 7 \pm 1 \cdot 1$ days after injection of PGF- $2 \alpha$, producing a $17 \cdot 5 \pm 1 \cdot 1$-day inter-oestrous interval. Mean serum concentrations of progesterone determined during the 22-day interval after the PG treatment are shown in Fig. 1. Ewes which received the PG-36 h-GnRH treatment responded similarly to the PG-treated ewes. Corpora haemorrhagica with visible papilli were observed via laparoscopy on the ovaries of 7/7 PG-36 h-GnRH-treated ewes 2 days after injection of GnRH. Although oestrus did not precede these ovulations, oestrus was observed $20 \cdot 1 \pm 1 \cdot 2$ days after injection of PGF-2 $\alpha$ as seen in the PG-treated ewes $(P \geq 0 \cdot 10)$. Profiles of serum concentrations of progesterone in PG-36 h-GnRH-treated ewes did not differ $(P \geq 0 \cdot 10)$ from those in PG-treated ewes (Fig. 1).

Laparoscopy of ewes in Groups GnRH-5h-PG and PG-5h-GnRH 2 days after injection of GnRH revealed that 5/7 and 5/7 ewes, respectively, had corpora haemorrhagica grossly identical to those observed in PG- and PG-36 h-GnRH-treated ewes. Like the PG-36 h-GnRH-treated ewes, oestrus did not accompany the GnRH-induced ovulations in GnRH-5 h-PG- and PG-5h-GnRHtreated ewes. Lifespan of CL which formed in response to an injection of $\mathrm{GnRH} 5 \mathrm{~h}$ before or $5 \mathrm{~h}$ after PGF-2 $\alpha$ (GnRH-5 h-PG and PG-5h-GnRH treated ewes, respectively) were short-lived with ewes returning to oestrus $4.5 \pm 1$ and $4.0 \pm 1$ days after PGF-2 $\alpha$. Laparoscopies performed at the onset of oestrus confirmed regression of the GnRH-induced CL. Serum concentrations of progesterone in GnRH-5 h-PG- and PG-5 h-GnRH-treated ewes which formed the short-lived CL did not exceed $0.5 \mathrm{ng} / \mathrm{ml}$ for more than 1 day (Fig. 1) before returning to oestrus. Corpora lutea which formed subsequent to those induced by the treatments of GnRH-5h-PG and PG-5h-GnRH produced oestrous cycle lengths $(17.7 \pm 1 \cdot 1$ and $18.5 \pm 0.5$ days, respectively) and profiles of serum concentrations of progesterone similar to those observed in PG-treated ewes $(P \geq 0 \cdot 10)$.

The 2/7 GnRH-5 h-PG- and 2/7 PG-5h-GnRH-treated ewes which did not ovulate within 2 days after injection of GnRH responded similarly to PG-treated ewes in terms of oestrus, oestrous cycle length and profiles of serum concentrations of progesterone (data not shown). 


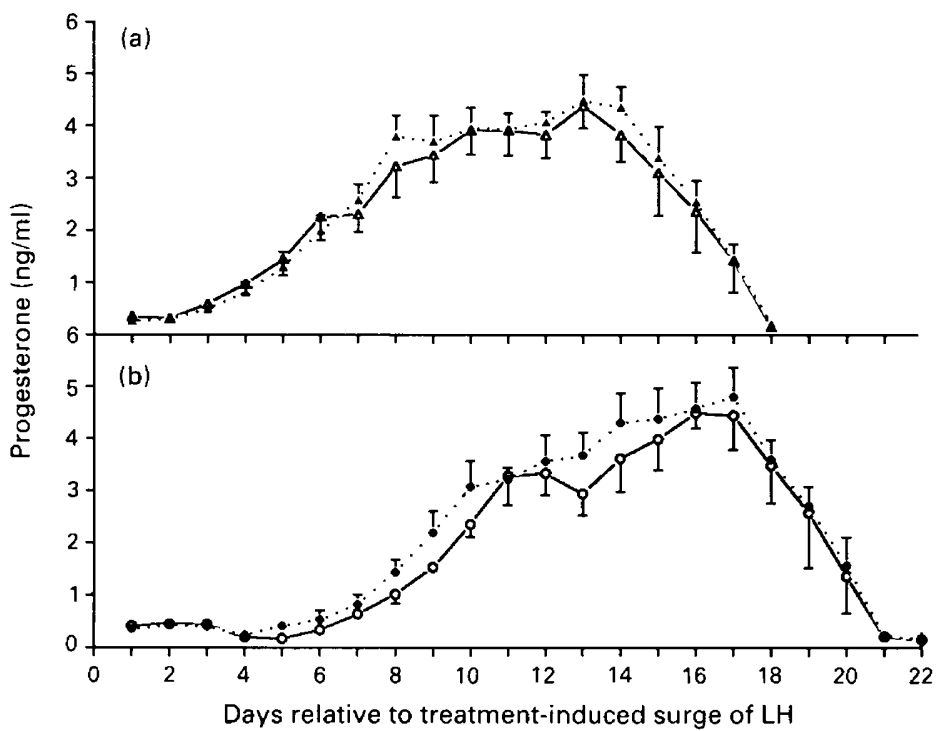

Fig. 1. Mean serum concentrations of progesterone in PG-treated ewes $(\mathbf{N}=8, \mathbf{\Delta}---\mathbf{\Delta})$ and ewes given $\mathrm{GnRH}$ before (GnRH-5 h-PG, O- $\mathrm{O}, \mathrm{N}=5$ ), during ( $\mathrm{PG}-5 \mathrm{~h}-\mathrm{GnRH}$, - - -, $\mathrm{N}=5$ ) or after (PG-36h-GnRH, $\triangle \triangle, N=7$ ) PGF-2 $\alpha$-induced luteal regression of the spontaneous CL. (a) Profiles of progesterone in ewes which formed CL with normal lifespans (i.e. PG- and PG-36 h-GnRH-treated ewes). (b) Profiles of progesterone in ewes which first formed subnormal CL followed by normal CL (i.e. GnRH-5 h-PG- and PG$5 \mathrm{~h}-$ GnRH-treated ewes).

\section{Experiment 3}

Of the 20 ewes assigned to GnRH-5 h-PG treatment and the 16 ewes assigned to the PG- $36 \mathrm{~h}-$ GnRH treatment, 14 and 16, respectively, had corpora haemorrhagica when examined at laparoscopy 2 days after injection of GnRH. Ewes without corpora haemorrhagica were not studied further. Ewes which received the GnRH-5 h-PG treatment and a control ear implant at laparoscopy $(\mathrm{N}=8)$ returned to oestrus before implant removal, $4.5 \pm 0.5$ days after injections of PGF-2 $\alpha$. When ovaries from ewes of this group were examined at oestrus (via laparoscopy), regression of the GnRH-induced $\mathrm{CL}$ was confirmed. Serum concentrations of progesterone determined during the interval from control implant placement until oestrus did not exceed $0.5 \mathrm{ng} / \mathrm{ml}$ for more than 1 day. In contrast, ewes which received the GnRH-5h-PG treatment and an implant containing $3 \mathrm{mg}$ norgestomet at laparoscopy $(\mathrm{N}=6)$ did not exhibit oestrus until $2 \cdot 6 \pm 0 \cdot 2$ days after implant removal (i.e. $12 \cdot 6 \pm 0 \cdot 2$ days after injection of PGF-2 $\alpha$ ), even though no luteal tissue was found in the ovaries at implant removal. Serum concentrations of progesterone determined during the interval from norgestomet implant placement until oestrus remained low and did not exceed $0.5 \mathrm{ng} / \mathrm{ml}$ for more than 1 day. Ewes which received the PG-36 h-GnRH treatment and either a blank $(\mathrm{N}=8)$ or norgestomet implant $(\mathrm{N}=8)$ had large, red $\mathrm{CL}$ located where corpora haemorrhagica had originally been situated following injection of GnRH when examined via laparoscopy at implant removal. No new ovulation sites were found. Profiles of serum concentrations of progesterone in $\mathrm{PG}-36 \mathrm{~h}-\mathrm{GnRH}$-treated ewes which received norgestomet implants were not different $(P \geq 0 \cdot 10)$ from those of PG-36h-GnRH-treated ewes which received control ear implants.

\section{Discussion}

In this series of studies, $74 \%(34 / 46)$ of cyclic ewes given $50 \mu \mathrm{g} \mathrm{GnRH}$ before excision of CL or PGF- $2 \alpha$-induced luteolysis of the Day 10 spontaneous CL formed corpora haemorrhagica within 2 
days after injection of GnRH. The observation that follicles capable of ovulating exist in the ovaries of some proportion of luteal-phase animals is not unique to this study and has been reported by other investigators administering a variety of hormones (Casida, 1946; Inskeep et al., 1963; Kiracofe \& Spies, 1966; Rahmanian \& Murdoch, 1987). Corpora lutea induced during the luteal phase of cyclic ewes did not affect lifespan of spontaneous CL (Casida et al., 1945; Inskeep et al., 1963; Rahmanian \& Murdoch, 1987). However, in the absence of spontaneous CL, there is evidence that the induced CL are inherently short-lived in uterine-intact ewes (Inskeep et al., 1963; Rahmanian \& Murdoch, 1987; present study). Removal of the uterus prevented the demise of the GnRH-induced CL in our studies, but not in the studies reported by Rahmanian \& Murdoch (1987). The reason for these contrasting observations is not known. It is known, however, that incomplete hysterectomy, delayed removal of the uterus and/or disruption of the ovarian blood vessels during hysterectomy could account for the short lifespan of induced CL in hysterectomized ewes (Rowson \& Moor, 1964; Kiracofe et al., 1966; Melampy \& Anderson, 1968; Anderson et al., 1969). Alternatively, function of the GnRH-induced subnormal CL may have waned in the hysterectomized ewes of Rahmanian \& Murdoch (1987) due to declining luteotrophic support reported to occur in ewes undergoing the transition from the breeding to non-breeding season (Karsch $e t$ al., 1984). Repeatedly, it has been reported that the demise of subnormal CL is dependent on the presence of the uterus (Keisler et al., 1983; Copelin et al., 1987; Lewis \& Bolt, 1987; Southee et al., 1988b).

The mechanism by which the uterine-dependent demise of the subnormal CL occurs is not well understood. Furthermore, the role, if any, of ovarian follicular development and secretions following CL formation in the uterine-dependent demise of the subnormal CL is also not known. When we attempted to reduce ovarian follicular development and secretions following CL formation in ewes with subnormal CL by implanting ewes with the synthetic progestagen, norgestomet, the CL regressed. This leads us to suggest that, after ovulation and CL formation, extra-luteal ovarian changes may play little or no role in dictating the demise of subnormal CL in ewes. The premature luteolytic mechanisms may therefore be established or initiated at or before ovulation. Zollers $e t$ al. (1988) and Copelin et al. (1989) have provided evidence to support the hypothesis that a premature release of PGF- $2 \alpha$ was responsible for the early demise of subnormal CL in cows. Even if a similar mechanism were operating in ewes, Acritopoulou \& Haresign (1980) reported that PGF-2 $\alpha$ was not capable of inducing regression of spontaneous (normal) CL before Day 3 . In our studies and those of Rahmanian \& Murdoch (1987), the lifespan of some of the GnRH-induced subnormal CL was no more than 3 days. Similar spontaneous (subnormal) CL are reported to occur at the onset of puberty in ewe lambs (Fitzgerald \& Butler, 1978; Ryan \& Foster, 1978; Berardinelli et al., 1980; Keisler et al., 1983), at the initiation of cyclic activity in post-partum ewes (Sharpe et al., 1986) and in ewes undergoing the transition into the breeding season (Walton et al., 1977). We therefore suggest that possibly two mechanisms are working simultaneously to hasten the demise of these and other subnormal CL; (1) that the luteolysin, PGF- $2 \alpha$, may be released earlier during the subnormal cycle than during the normal cycle to hasten the demise of the subnormal CL and (2) that the induced CL may have formed from a follicle which had not experienced some sequence of events characteristic of luteal regression and/or a normal follicular phase (i.e. inadequate follicle development), and therefore is in some way more responsive to or responsible for premature luteolysis. The observation in Exp. 1 that GnRH-induced subnormal CL in hysterectomized ewes failed to produce serum concentrations of progesterone equal to that of mid-luteal phase spontaneous CL in cyclic ewes may indicate that a luteal defect exists in the GnRH-induced subnormal CL. While other explanations are possible, it is clear, in these and other studies (Southee et al., 1988b), that in the absence of the uterus the subnormal CL failed to attain the secretory capacity of a normal CL in the presence of a uterus. Should a luteal-phase defect exist as suggested in these and other studies (Haresign \& Lamming, 1978; McNatty, 1979; McNatty et al., 1981; diZerega \& Hodgen, 1981; McLeod et al., 1982; Legan et al., 1985), it may be attributed to inadequate development of the follicle from which the subnormal CL formed, as suggested from the results of Exp. 2. Together, 
these data and the results obtained in Exp. 2 provide evidence that the endocrine environment to which preovulatory follicles are exposed before ovulation may be important in dictating their ability to form normal or subnormal CL. Inskeep et al. (1988) have suggested that an integral relationship exists between the development of a follicle destined to form a CL and the lifespan of that CL. Specifically, Inskeep et al. (1988) and White et al. (1987) reported that follicles destined to form subnormal CL had less oestradiol in the follicular fluid than did follicles destined to form normal CL. Based on these suggestions, we would suggest that follicles which were induced to form subnormal $\mathrm{CL}$ in the GnRH-5 h-PG- and PG-5h-GnRH-treated ewes in Exp. 2 had lower concentrations of oestradiol than did follicles induced to form normal CL in the PG-36 h-GnRH treated ewes. Ewes induced to ovulate before, during or after luteal regression, in the present studies (Exp. 2), were not observed in oestrus before GnRH-induced ovulation. Deaver et al. (1986), however, reported that serum concentrations of oestradiol began to increase following injection of PGF-2 $\alpha$ into ewes on Day 11 and were significantly elevated by $30 \mathrm{~h}$ after injection of PGF-2 $\alpha$. The suspected lower serum concentrations of oestradiol in GnRH-5 h-PG- and PG-5 hGnRH-treated ewes may have caused a decreased synthesis of uterine progesterone receptors, which in turn allowed the timing of uterine PGF- $2 \alpha$ secretion to be advanced, as suggested by Inskeep et al. (1988). Oestradiol, therefore, may be serving as an indicator of follicular development and a regulator of uterine PGF- $2 \alpha$ secretion. Based on our preliminary observations in a limited number of ewes, pretreatment of GnRH-5 h-PG-treated ewes with physiological levels of oestradiol failed to enhance luteal function (unpublished observations).

We suggest that these data provide new evidence to support the hypothesis that subnormal luteal function may be the result of inadequate follicle development (i.e. the follicle needs exposure to some sequence of events characteristic of luteal regression and/or a normal follicular phase) which impairs uterine luteolytic mechanisms. Furthermore, these results support the hypothesis that periovulatory determinants of normal luteal function are established between 5 and $36 \mathrm{~h}$ after PGF-2 $\alpha$-induced luteal regression.

We thank Dr R. L. Butcher, West Virginia University, for the progesterone antiserum; Dr G. D. Niswender, Colorado State University, for the LH antiserum; Dr L. E. Reichert, Jr, Albany Medical College, for purified preparations of LH for iodination; NIADDK for oLH-24 standards; Ceva Laboratories, Inc., for the gift of GnRH; and The UpJohn Company for the gift of PGF-2 $\alpha$. This paper is a contribution from the Missouri Agricultural Experiment Station Journal Series No. 1074l and Regional Research Project W112, Reproductive Performance in Domestic Ruminants.

\section{References}

Acritopoulou, S. \& Haresign, W. (1980) Response of ewes to a single injection of an analogue of PGF-2 $\alpha$ given at different stages of the oestrous cycle. J. Reprod. Fert. 58, 219-223.

Anderson, L.L., Bland, K.P. \& Melampy, R.M. (1969) Comparative aspects of uterine-luteal relationships. Recent Prog. Horm. Res. 25, 57-99.

Becker, W.A. (1984) Repeatability. In: Manual of Quantitative Genetics, pp. 35-40. Academic Enterprises, Pullman.

Berardinelli, J.G., Dailey, R.A., Butcher, R.L. \& Inskeep, E.K. (1979) Source of progesterone prior to puberty in beef heifers. J. Anim. Sci. 49, 1276-1280.

Berardinelli, J.G., Dailey, R.A., Butcher, R.L. \& Inskeep, E.K. (1980) Source of circulating progesterone in prepubertal ewes. Biol. Reprod. 22, 233-236.

Casida, L.E. (1946) Induction of ovulation and subsequent fertility in domestic animals. In The Problem of Fertility, pp. 49-59. Ed. E. T. Engle. Princeton University Press, Princeton.

Casida, L.E., Dutt, R.H. \& Meyer, R.K. (1945) Alteration of the estrual cycle by pituitary gonadotropins and persistence of the effects upon reproductive performance in ewes. J. Anim. Sci. 4, 24-33.

Coleman, D.A. \& Dailey, R.A. (1983) Effects of repeated removal of large ovarian follicles and treatment with progestin on ovarian function in the ewe. Biol. Reprod. 29, 586-593.

Copelin, J.P., Smith, M.F., Garverick, H.A. \& Youngquist, R.S. (1987) Effect of the uterus on subnormal luteal function in anestrous beef cows. J. Anim. Sci. 64, 1506-1511.

Copelin, J.P., Smith, M.F., Keisler, D.H. \& Garverick, H.A. (1989) Effect of active immunization of prepartum and post-partum cows against prostaglandin F-2 $\alpha$ on lifespan and progesterone secretion of Downloaded from Bioscientifica.com at $04 / 26 / 2023$ 12:42:51PM via free access 
short-lived corpora lutea. J. Reprod. Fert. 87, 199-207.

Corah, L.R., Quealy, A.P., Dunn, T.G. \& Kaltenbach, C.C. (1974) Prepartum and postpartum levels of progesterone and estradiol in beef heifers fed two levels of energy. J. Anim. Sci. 39, 380-385.

Deaver, D.R., Stilley, N.J., Dailey, R.A., Inskeep, E.K. \& Lewis, P.E. (1986) Concentrations of ovarian and pituitary hormones following prostaglandin $F_{2 a}$ induced luteal regression in ewes varies with day of the estrous cycle at treatment. J. Anim. Sci. 62, 422-427.

diZerega, G.J. \& Hodgen, G.D. (1981) Luteal phase dysfunction infertility: a sequel to aberrant folliculogenesis. Fert. Steril. 35, $489-499$.

Fitzgerald, J.A. \& Butler, W.R. (1978) Reproductive hormone patterns from birth to puberty in ewe lambs. Biol. Reprod. 18 (Suppl. 1), Abstr. 55.

Garcia-Winder, M., Lewis, P.E., Deaver, D.R., Smith, V.G., Lewis, G.S. \& Inskeep, E.K. (1986) Endocrine profiles associated with life span of induced corpora lutea in postpartum beef cows. J. Anim. Sci. 62, 1353-1362.

Garverick, H.A. \& Smith, M.F. (1986) Mechanisms associated with subnormal luteal function. J. Anim. Sci. 62 (Suppl. 2), 92-105.

Haresign, W. \& Lamming, G.E. (1978) Comparison of LH release and luteal function in cyclic and LH-RHtreated anoestrous ewes pretreated with PMSG or oestrogen. J. Reprod. Fert. 52, 349-353.

Inskeep, E.K., Oloufa, M.M., Pope, A.L. \& Casida, L.E. (1963) Functional capabilities of experimentally induced corpora lutea in ewes. J. Anim. Sci. 22, 159-161.

Inskeep, E.K., Braden, T.D., Lewis, P.E., Garcia-Winder, M. \& Niswender, G.D. (1988) Receptors for luteinizing hormone and follicle-stimulating hormone in largest follicles of postpartum beef cows. Biol. Reprod. 38, 587-591.

Jones, G.S. (1976) The luteal phase defect. Fert. Steril. 27, 351-356.

Karsch, F.J., Bittman, E.L., Foster, D.L., Goodman, R.L., Legan, S.J. \& Robinson, J.E. (1984) Neuroendocrine basis of seasonal reproduction. Recent Prog. Horm. Res. 40, 185-232.

Keisler, D.H., Inskeep, E.K. \& Dailey, R.A. (1983) First luteal tissue in ewe lambs: Influence on subsequent ovarian activity and response to hysterectomy. $J$. Anim. Sci. 57, 150-156.

Kiracofe, G.H. \& Spies, H.G. (1966) Length of maintenance of naturally formed and experimentally induced corpora lutea in hysterectomized ewes. J. Reprod. Fert. 11, 275-279.

Kiracofe, G.H., Menzies, C.S., Gier, H.T. \& Spies, H.G. (1966) Effect of uterine extracts and uterine or ovarian blood vessel ligations on ovarian function of ewes. J. Anim. Sci. 25, 1159-1163.

Lamming, G.E., Wathes, D.C. \& Peters, A.R. (1981) Endocrine patterns of the post-partum cow. $J$. Reprod. Fert., Suppl. 30, 155-170.

LaVoie, V., Han, D.K., Foster, D.B. \& Moody, E.L. (1981) Suckling effect on estrus and blood plasma progesterone in postpartum beef cows. J. Anim. Sci. 52, 802-812.

Legan, S.J., I'Anson, H., Fitzgerald, B.P. \& Akaydin,
M.S., Jr (1985) Importance of short luteal phases in the endocrine mechanism controlling initiation of estrous cycles in anoestrous ewes. Endocrinology 117, 1530-1536.

Lewis, G.S. \& Bolt, D.J. (1987) Effects of suckling, progestogen-impregnated pessaries or hysterectomy on ovarian function in autumn-iambing postpartum ewes. J. Anim. Sci. 64, 216-225.

Lishman, A. W., Allison, S.M.J., Fogwell, R.L., Butcher, R.L. \& Inskeep, E.K. (1979) Follicular development and function of induced corpora lutea in underfed postpartum anestrous beef cows. J. Anim. Sci. 48, 867-875.

McLeod, B.J. \& Haresign, W. (1984) Evidence that progesterone may influence subsequent luteal function in the ewe by modulating preovulatory follicle development. J. Reprod. Fert. 71, 381-386.

McLeod, B.J., Haresign, W. \& Lamming, G.E. (1982) Response of seasonally anoestrous ewes to smalldose multiple injections of Gn-RH with and without progesterone pretreatment. J. Reprod. Fert. 65, $223-230$.

McNatty, K.P. (1979) Follicular determinants of corpus luteum function in the human ovary. Adv. exp. Med. Biol. 112, 465-482.

MeNatty, K.P., Gibb, M., Dobson, C. \& Thurley, D.C. (I981) Evidence that changes in luteinizing hormone secretion regulate the growth of the preovulatory follicle in the ewe. J. Endocr. 90, 375-389.

Melampy, R.M. \& Anderson, L.L. (1968) Role of the uterus in corpus luteum function. J. Anim. Sci. 27 (Suppl. 1), 77-96.

Odde, K.G., Ward, H.S., Kiracofe, G.H., McKee, R.M. \& Kittok, R.J. (1980) Short estrous cycles and associated serum progesterone levels in beef cows. Theriogenology 14, 105-112.

Pratt, B.R., Berardinelli, G., Stevens, L.P. \& Inskeep, E.K. (1982) Induced corpora lutea in the postpartum beef cow. I. Comparison of $\mathrm{GnRH}$ and human chorionic gonadotropin and effects of progestogen and estrogen. J. Anim. Sci. 54, 822-829.

Rahmanian, M.S. \& Murdoch, W.J. (1987) Function of ovine corpora lutea after administration of luteinizing hormone-releasing hormone. J. Anim. Sci. 64, 648-655.

Rowson, L.E.A. \& Moor, R. (1964) Effect of partial hysterectomy on the length of the dioestrous interval in sheep. Proc. 5th Int. Congr. Anim. Reprod. \& A.I., Trento 2, 394-398.

Ryan, K.D. \& Foster, D.L. (1978) Two LH surges at puberty in the female lamb: Possible role of progesterone. Biol. Reprod. 18 (Suppl. 1), Abstr. 58.

SAS Institute, Inc. (1985) SAS User's Guide: Statistics, Version 5 Edition, pp. 433-507. SAS Institute, Cary.

Sharpe, P.H., McKibbin, P.E., Murphy, B.D. \& Manns, J.G. (1986) First postpartum ovulations and corpora lutea in ewes which lamb in the breeding season. Anim. Reprod. Sci. 10, 61-74.

Shefiel, C.E., Pratt, B.R., Ferrell, W.L. \& Inskeep, E.K. (1982) Induced corpora lutea in the postpartum beef cow. II. Effects of treatment with progestogen and gonadotropins. J. Anim. Sci. 54, 830-836.

Soules, M.R., Wiebe, R.H., Aksel, S. \& Hammond, C.B. (1977) The diagnosis and therapy of luteal phase deficiency. Fert. Steril. 28, 1033-1037. 
Southee, J.A., Hunter, M.G. \& Haresign, W. (1988a) Function of abnormal corpora lutea in vivo after GnRH-induced ovulation in the anoestrous ewe. $J$. Reprod. Fert. 84, 131-137.

Southee, J.A., Hunter, M.G., Law, A.S. \& Haresign, W. (1988b) Effect of hysterectomy on the short life-cycle corpus luteum produced after GnRH-induced ovulation in the anoestrous ewes. J. Reprod. Fert. 84, 149-155.

Steel, R.G.D. \& Torrie, J.H. (1980) Principles and Procedures of Statistics. A Biometrical Approach. McGraw-Hill Book Co., New York.

Strott, C.A., Cargille, C.M., Ross, G.T. \& Lipsett, M.B. (1970) The short luteal phase. J. clin. Endocr. Metab. 30, 246-251.

Walton, J.S., McNeilly, J.R., McNeilly, A.S. \& Cunningham, F.J. (1977) Changes in concentrations of follicle stimulating hormone, luteinizing hormone, prolactin and progesterone in the plasma of ewes during the transition from anoestrous to breeding activity. J. Endocr. 75, 127-136.
White, L.M., Keisler, D.H., Dailey, R.A. \& Inskeep, E.K. (1987) Characterization of ovine follicles destined to form subfunctional corpora lutea. J. Anim. Sci. 65, 1595-1601.

Wilks, J.W., Hodgen, G.D. \& Ross, G.T. (1976) Lutealphase defects in the rhesus monkeys: the significance of serum FSH:LH ratio. J. clin. Endocr. Metab. 43, 1261-1267.

Zaied, A.A., Garverick, H.A., Bierschwal, C.J., Elmore, R.G., Youngquist, R.S. \& Sharp, A.J. (1980) Effect of ovarian activity and endogenous reproductive hormones on GnRH-induced ovarian cycles in postpartum dairy cows. J. Anim. Sci. 50, 508-513.

Zollers, W.G., Garverick, H.A. \& Smith, M.F. (1988) Serum concentrations of 15-keto-13,14 dihydroPGF-2 $\alpha$ (PGFM) following oxytocin injection during the first postpartum estrous cycle of beef cows. $J$. Anim. Sci. 66 (Suppl. 1), 434, Abstr.

Received 24 January 1989 